\title{
Vici syndrome in an Egyptian infant: case report and differential diagnosis of inherited hypopigmented disorders
}

\author{
Marwa Abd Elmaksoud ${ }^{1 *} \mathbb{D}$, Aya Attya Abeesh ${ }^{2}$, Catarina Pereira ${ }^{3}$ and Marwa El-Saeed El-Deeb ${ }^{4}$
}

\begin{abstract}
Background: Vici syndrome is a severe inherited multisystem disease caused by mutations in the EPG5 gene. The diagnosis depends on the constellation of cardinal features of agenesis of the corpus callosum, cataracts, oculocutaneous hypopigmentation, cardiomyopathy, and a combined immunodeficiency followed by confirmation by genetic testing. We report an Egyptian infant with Vici syndrome carrying a homozygous splice site variant (c.1252+1G>T; NM_020964.2) in the EPG5 gene, detailed clinical description, outcome, and differential diagnosis of inherited hypopigmentation disorders associated with neurological manifestations.
\end{abstract}

Case presentation: The infant initially presented with oculocutaneous hypopigmentation, agenesis of the corpus callosum, and immunodeficiency. A few months later, a diagnosis of dilated cardiomyopathy was made. Family history revealed 2 deceased siblings phenotypically matching our index infant. He died at the age of 15 months with acute respiratory failure.

Conclusion: The accurate diagnosis of such rare diseases with genetic confirmation is vital for proper clinical decision-making, genetic counseling of the affected families, and future genotype-phenotype correlation studies.

Keywords: Vici, Syndrome, Hypopigmentation, Infant, Case report

\section{Background}

Vici syndrome (OMIM 242840) is a severe autosomal recessive multisystem disease characterized by agenesis of the corpus callosum, cataracts, oculocutaneous hypopigmentation, cardiomyopathy, and combined immunodeficiency. This rare disorder was first described by Dionisi Vici and colleagues in 1988 [1], and since then, 82 genetically confirmed cases have been reported, not including ours [2-4].

Mutations of the ectopic P-granules autophagy protein 5 homolog (EPG5) gene, on chromosome 18q, were first documented as the underlying etiology of Vici syndrome in 2013 [5]. The EPG5 protein has a key role as a regulator of autophagy, which is a fundamental cellular

\footnotetext{
*Correspondence: m_abdelmaksoud16@alexmed.edu.eg

'Department of Pediatrics, Neurology Unit, Faculty of Medicine, Alexandria

University, Alexandria, Egypt

Full list of author information is available at the end of the article
}

degradative pathway. This process is enhanced in the neurons and muscles, which might explain the prominent CNS, neuromuscular involvement, and multisystem affection in patients with Vici syndrome [6]. To date, nearly 40 different EPG5 mutations have been identified without clear genotype-phenotype correlations [6].

We report an Egyptian infant with genetically confirmed Vici syndrome with a detailed clinical description, course of the disease, genetic mutations, and differential diagnosis of some of the inherited hypopigmentation disorders associated with neurological manifestations (Table 1).

\section{Case presentation}

At the time of examination, our index patient was a 2month-old male infant born to consanguineous parents (first-degree cousins). Family history revealed 2 deceased siblings; a male and a female infant who had passed

\section{Springer Open}

(c) The Author(s). 2020 Open Access This article is licensed under a Creative Commons Attribution 4.0 International License, which permits use, sharing, adaptation, distribution and reproduction in any medium or format, as long as you give appropriate credit to the original author(s) and the source, provide a link to the Creative Commons licence, and indicate if changes were made. The images or other third party material in this article are included in the article's Creative Commons licence, unless indicated otherwise in a credit line to the material. If material is not included in the article's Creative Commons licence and your intended use is not permitted by statutory regulation or exceeds the permitted use, you will need to obtain permission directly from the copyright holder. To view a copy of this licence, visit http://creativecommons.org/licenses/by/4.0/. 
Table 1 Differential diagnosis inherited hypopigmentation disorders associated with neurological manifestations

\begin{tabular}{|c|c|c|c|c|c|}
\hline Syndrome & Gene defect & Skin features & Neurological features & Other associated features & Investigations \\
\hline $\begin{array}{l}\text { Chediak-Higashi } \\
\text { syndrome (CHS) }\end{array}$ & $\begin{array}{l}\text { AR } \\
\text { LYST gene } \\
\text { defect } \\
\text { (1q42-43) }\end{array}$ & $\begin{array}{l}\text { Partial albinism, with } \\
\text { a peculiar silvery gray } \\
\text { scalp hair, eyebrows, } \\
\text { and eyelashes }\end{array}$ & $\begin{array}{l}\text { Present either: } \\
\text { 1) Primary, e.g., } \\
\text { developmental } \\
\text { abnormalities as } \\
\text { learning disabilities } \\
\text { 2) Secondary to the } \\
\text { accelerated phase } \\
\text { of CNS-HLH or CNS } \\
\text { infections }\end{array}$ & $\begin{array}{l}\text { 1) Immunodeficiency with } \\
\text { repeated and persistent } \\
\text { infections } \\
\text { 2) Hyperinflammation with } \\
\text { secondary HLH }\end{array}$ & $\begin{array}{l}\text { Peripheral blood/bone } \\
\text { marrow smear reveals } \\
\text { giant azurophilic granules } \\
\text { within neutrophils/leukocyte } \\
\text { precursor cells. } \\
\text { Hair Trichogram reveals } \\
\text { small clumped melanin } \\
\text { granules, regularly arranged. }\end{array}$ \\
\hline $\begin{array}{l}\text { Oculocerebral } \\
\text { hypopigmentation } \\
\text { syndrome, OHS } \\
\text { (cross-type) }\end{array}$ & $\begin{array}{l}\text { AR } \\
\text { Unknown } \\
\text { gene defect } \\
\text { (3q27.1q29) }\end{array}$ & $\begin{array}{l}\text { Generalized } \\
\text { hypopigmentation } \\
\text { with photosensitivity } \\
\text { Silvery scalp hair, } \\
\text { eyebrows, and } \\
\text { eyelashes }\end{array}$ & $\begin{array}{l}\text { Psychomotor delay } \\
\text { with athetoid } \\
\text { movements, ataxia, } \\
\text { spasticity, joint } \\
\text { contractures, and } \\
\text { intellectual disability }\end{array}$ & $\begin{array}{l}\text { Ophthalmological } \\
\text { manifestations: } \\
\text { microphthalmia and } \\
\text { microcornea } \\
\text { Growth retardation } \\
\text { Distinctive facies: } \\
\text { dolichocephaly, a highly } \\
\text { arched palate, widely } \\
\text { spaced teeth } \\
\text { High-pitched cry } \\
\text { Oligophrenia }\end{array}$ & \\
\hline Griscelli syndrome & AR & $\begin{array}{l}\text { Partial albinism with } \\
\text { silvery gray scalp hair, } \\
\text { eyebrows, and } \\
\text { eyelashes }\end{array}$ & & & $\begin{array}{l}\text { Trichogram reveals large } \\
\text { melanin clumps unevenly } \\
\text { distributed. }\end{array}$ \\
\hline $\begin{array}{l}\text { GS1/Elejalde } \\
\text { syndrome }\end{array}$ & $\begin{array}{l}\text { MYO5A } \\
(15 q 21 .)\end{array}$ & & $\begin{array}{l}\text { GS1: hypotonia, } \\
\text { encephalopathy, } \\
\text { seizures, and } \\
\text { psychomotor delay }\end{array}$ & GS1: no immne dysfunction & \\
\hline GS2 & $\begin{array}{l}\text { RAB2A } \\
(15 q 21 .)\end{array}$ & & $\begin{array}{l}\text { GS2: neurologic } \\
\text { manifestations in } \\
\text { association with the } \\
\text { accelerated phase } \\
\text { CNS-HLH }\end{array}$ & $\begin{array}{l}\text { GS2: immune dysfunction } \\
\text { is evident. }\end{array}$ & \\
\hline $\begin{array}{l}\text { Prader-Willi } \\
\text { syndrome }\end{array}$ & $\begin{array}{l}\text { Defective } \\
\text { region of } \\
\text { chromosome } 15 \\
(15 q 11.2-q 13)\end{array}$ & $\begin{array}{l}\text { Hypopigmentation of } \\
\text { the hair, eyes, and skin }\end{array}$ & $\begin{array}{l}\text { Hypotonia, cognitive } \\
\text { impairment, and } \\
\text { developmental delay }\end{array}$ & $\begin{array}{l}\text { Distinctive facies: } \\
\text { dolicoceohaly with } \\
\text { almond-shaped eyes, a } \\
\text { thin upper lip, a } \\
\text { downturned mouth, } \\
\text { hyperphagia with morbid } \\
\text { obesity, and } \\
\text { hypogonadism with } \\
\text { delayed puberty }\end{array}$ & \\
\hline $\begin{array}{l}\text { Angelman } \\
\text { syndrome }\end{array}$ & $\begin{array}{l}\text { Defective } \\
\text { region of } \\
\text { chromosome } \\
15 \text { involving } \\
\text { the UBE3A } \\
\text { gene }\end{array}$ & Fair skin and hair & $\begin{array}{l}\text { Intellectual disability } \\
\text { and seizures } \\
\text { Behavioral features: } \\
\text { happy, excitable } \\
\text { demeanor with } \\
\text { frequent smiling, } \\
\text { laughter, and } \\
\text { hand-flapping } \\
\text { movements }\end{array}$ & Microcephaly and scoliosis & \\
\hline Phenylketonuria & $\begin{array}{l}\text { AR } \\
\text { PAH gene } \\
\text { defect } \\
(12 q 23.2)\end{array}$ & $\begin{array}{l}\text { Fair skin and hair, } \\
\text { eczema } \\
\text { photosensitivity, } \\
\text { keratosis pilaris, and } \\
\text { scleroderma-like } \\
\text { plaques }\end{array}$ & $\begin{array}{l}\text { Progressive } \\
\text { developmental delay } \\
\text { and intellectual } \\
\text { disability } \\
\text { Epilepsy } \\
\text { Extrapyramidal } \\
\text { manifestation }\end{array}$ & Musty or mousy odor & $\begin{array}{l}\text { The upper reference limit } \\
\text { for Phe in whole blood } \\
\text { or plasma in neonates is } \\
<150 \mu \mathrm{mol} / \mathrm{L} \text { and slightly } \\
\text { lower }(<120 \mu \mathrm{mol} / \mathrm{L}) \text { in } \\
\text { older children. }\end{array}$ \\
\hline Menkes syndrome & $\begin{array}{l}X L R \\
\text { Defective } \\
\text { ATP7A gene } \\
\text { (Xq13.3) }\end{array}$ & $\begin{array}{l}\text { Abnormal kinky hair } \\
\text { (short, sparse, coarse, } \\
\text { twisted often hypo } \\
\text { or depigmented) } \\
\text { especially in the areas } \\
\text { of friction }\end{array}$ & $\begin{array}{l}\text { Resistant seizures, } \\
\text { developmental } \\
\text { regression spasticity, } \\
\text { and weakness of the } \\
\text { extremities }\end{array}$ & $\begin{array}{l}\text { Skeletal changes, including } \\
\text { pectus excavatum and } \\
\text { spontaneous fractures due } \\
\text { to generalized osteoporosis. } \\
\text { The joints are hyperextensive, } \\
\text { and loose. }\end{array}$ & $\begin{array}{l}\text { Trichogram can reveal } \\
\text { pili torti. }\end{array}$ \\
\hline $\begin{array}{l}\text { Hypomelanosis } \\
\text { of Ito }\end{array}$ & $\begin{array}{l}\text { Postzygotic } \\
\text { mutations in } \\
\text { a variety of } \\
\text { pigmentation-associated } \\
\text { genes }\end{array}$ & $\begin{array}{l}\text { Unilateral or bilateral } \\
\text { cutaneous macular } \\
\text { hypopigmented } \\
\text { whorls, streaks, and } \\
\text { patches along the } \\
\text { lines of Blaschko }\end{array}$ & $\begin{array}{l}\text { Seizures, mental } \\
\text { retardation, } \\
\text { developmental delay, } \\
\text { cerebral malformations, } \\
\text { hypotonia, deafness, } \\
\text { and visual problems }\end{array}$ & $\begin{array}{l}\text { Glomerulocystic kidney } \\
\text { disease } \\
\text { Skeletal abnormalities } \\
\text { Dental abnormalities }\end{array}$ & \\
\hline
\end{tabular}


away at the age of 3 and 2 months, respectively. The male sibling died after a few days of acute gastroenteritis with severe dehydration complicated by septic shock. The female sibling died due to severe acute bacterial meningitis. Both deceased siblings had characteristic hypopigmented hair and skin, phenotypically matching our index infant but not the parents, the healthy 10-year-old brother, or other family members (Fig. 1).

The antenatal history was uneventful; he was born at term by normal vaginal delivery. However, postnatally, he was admitted to the neonatal intensive care unit (NICU) for 10 days immediately after birth due to earlyonset sepsis as blood culture revealed Klebsiella pneumoniae (K. pneumoniae). Following discharge from the NICU, he spent only 2 days at home and was readmitted for 20 days with fever and refusal of feeding. His initial examination showed characteristic fair hair and skin with dysmorphic facial features including receding mandible and low-set ears. His anthropometric measures for weight and height were decreased for his age and sex: body weight $=3 \mathrm{~kg}(Z$ score $=-3.97)$, length $=55 \mathrm{~cm}(Z$ score $=-2)$, while head circumference $=38 \mathrm{~cm}(Z$ score $=-1.63)$. Generally, he was hypoactive and visually inattentive with generalized hypotonia, a tuft of hair on his lower back over the sacral region, and talipes equinovarus of the left foot (Fig. 1). A trans-cranial ultrasound revealed agenesis of the corpus callosum, and his echocardiogram showed patent foramen oval (PFO). Vici syndrome was suspected, and further investigations were requested.
Laboratory investigation including complete blood count $(\mathrm{CBC})$, renal and liver function tests, serum lactate, pyruvate, ammonia, extended metabolic screen, and urinary organic acid profile were all within the normal range. His immunological profile including $\mathrm{T}$ and $\mathrm{B}$ cell quantitative analysis confirmed that the total number of $\mathrm{T}$ cells and the CD8+ cell population was decreased compared to the normal ranges corresponding to the patient's age. On the other hand, his immunoglobulin profile was normal for his age: IgG $452 \mathrm{mg} / \mathrm{dl}$ (normal 445-1050), IgA $37 \mathrm{mg} / \mathrm{dl}$ (normal 20-60), and IgM 63 $\mathrm{mg} / \mathrm{dl}$ (normal 30-80). Workup also included a hair trichogram, which showed an absent medulla and a decrease in pigmentation (Fig. 1).

Brain magnetic resonance imaging (MRI) showed evidence of agenesis of the corpus callosum (ACC) and atrophic brain changes, while his spine MRI revealed normal cord and spine structure with no evidence of neural tube defects. The ophthalmological evaluation reported hypopigmented fundus and decreased foveal reflex. An Auditory Brainstem Response test (ABR) showed moderate to severe hearing loss at high frequencies $(2-4 \mathrm{kHz})$ in his left ear.

Following the parents' written consent, blood samples of the patient and his parents were drawn, and DNA was extracted. Targeted next-generation sequencing of EPG5 revealed a homozygous c.1252+1G $>\mathrm{T}$ (NM 020964.2) variant in our patient. This change was classified as a likely pathogenic change [7], was found in the Genome Aggregation Database (gnomAD) only once and in a heterozygous state (allele frequency

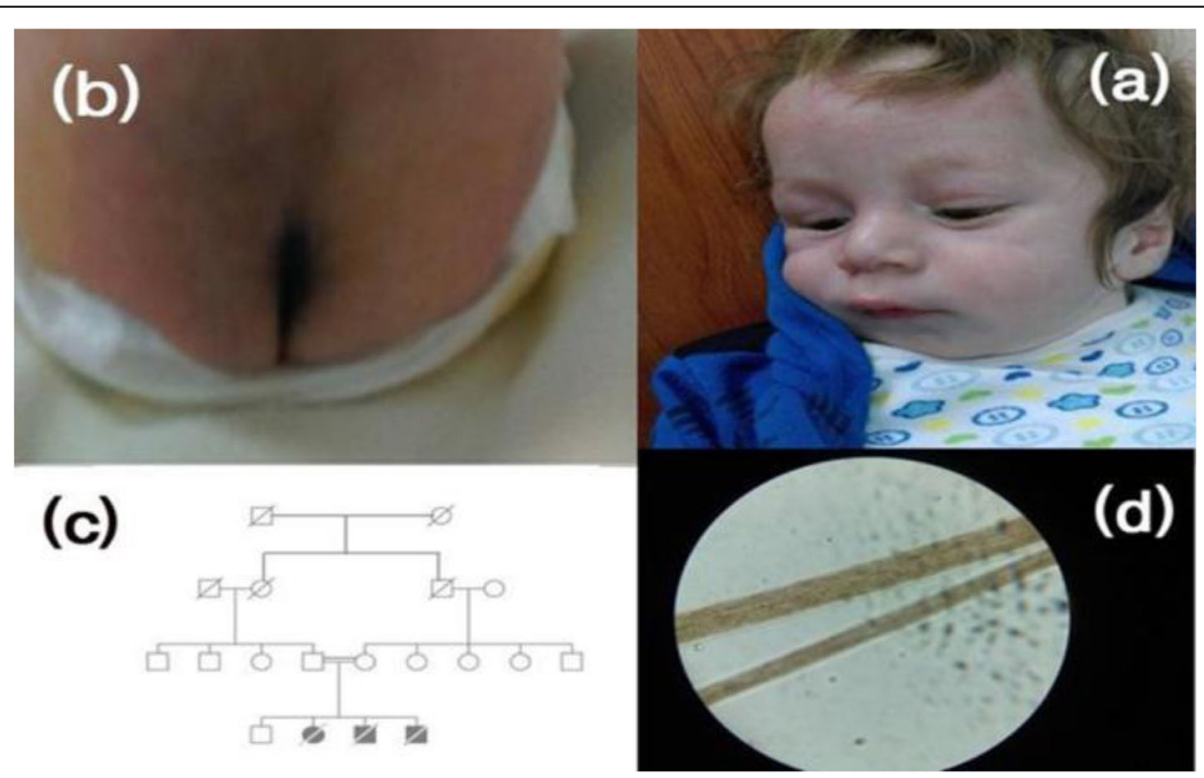

Fig. 1 a The phenotype of the index case shows hypopigmented hair and skin, $\mathbf{b}$ tuft of hair on the index patient's lower back over the sacral region, $\mathbf{c}$ the family pedigree, and $\mathbf{d}$ hair trichogram showing an absent medulla and a decrease in pigmentation. 
0.000004013), and has a Combined Annotation Dependent Depletion (CADD) score of 33 [8]. Using targeted Sanger sequencing, the same alteration was detected in each of the parents in a heterozygous state.

By the age of 6 months, he was admitted due to respiratory distress, and a diagnosis of dilated cardiomyopathy was made as his echocardiography (ECHO) revealed significant left ventricular end-diastolic dilation with decreased ejection fraction $(E F=40 \%)$ for which Lanoxin (digoxin) and diuretics (Frusemide) were prescribed. Due to frequent infections, the patient was put on a prophylactic dose of sulfamethoxazole and trimethoprim $\left(150 \mathrm{mg} / \mathrm{m}^{2} /\right.$ day $)$ every other day and monthly intravenous immunoglobulin (IVIG) $(400 \mathrm{mg} /$ $\mathrm{kg}$ once every 4 weeks). By the age of 12 months, he experienced repeated hospital admissions due to recurrent respiratory and gastrointestinal tract infections. Acute infections were treated with broad-spectrum antibiotics (including ceftriaxone, meropenem, vancomycin, fluconazole) and intravenous immunoglobulin IVIG (400 mg/ $\mathrm{kg} /$ day for 5 days). Despite the abovementioned treatments, he died at the age of 15 months from acute respiratory failure due to extensive acute bacterial pneumonia.

\section{Discussion}

Vici syndrome is a rare hereditary disease with a diagnosis that depends on the constellation of five main cardinal features: agenesis of the corpus callosum, cataracts, oculocutaneous hypopigmentation, cardiomyopathy, and a combined immunodeficiency, which are found in almost all reported cases of Vici syndrome [6]. In addition, more recently recognized but equally consistent features include profound developmental delay, progressive microcephaly, and failure to thrive [9]. Furthermore, a wide range of additional findings has been reported in isolated cases including features such as hearing loss, lung hypoplasia, renal tubular necrosis, idiopathic thrombocytopenic purpura, and myopathy [10-13].

The initial presentation of our case included four out of the five classical features: oculocutaneous hypopigmentation, immunodeficiency, and agenesis of the corpus callosum. Cardiomyopathy developed a few months later following his initial presentation and is consistent with other reported cases in which initial echocardiography was normal. Thus, regular follow-up with ECHO for any suspected case of Vici syndrome is of crucial importance [14].

Moreover, our patient had profound developmental delay and failure to thrive, representing six out of the eight key features that were found to have a specificity of $97 \%$ and a sensitivity of $89 \%$ for cases with a positive EPG5 genetic test [9]. Other less common manifestations in our case included facial dysmorphism in the form of receding mandible and low-set ears, reported by Said et.al [15]. and Vojcek et al. [4]. Other dysmorphic features reported in some children with Vici syndrome include cleft lip and palate, hypertelorism, high-arched palate, micrognathia $[1,13,16,17]$, coarse facial features [5, 9], small anterior fontanelle with overlapping sutures, and broad nose [10], and Epicanthal folds were being reported less frequently [3].

Our index case had a hearing defect, which has been reported in a very few cases, specifically the sensory neural hearing loss subtype (SNHL) $[4,10,17,18]$. However, we believe that it might be frequently unrecognized because of the overwhelming multisystem effects of Vici syndrome that may present very early in life and cause early death. Therefore, although ABR was not included as a baseline investigation for the diagnosis of a patient with suspected Vici syndrome, it should be investigated [6]. Moreover, the index case showed a tuft of hair on his lower back over the sacral region and talipes equinovarus of the left foot, which are reported here for the first time in Vici syndrome.

Other neurological manifestations of Vici syndrome, besides developmental delay, hearing deficits, and hypotonia documented in our case, include seizures, myopathy, progressive microcephaly, and neuropathy which have been reported in more than half of the children [6]. CNS affection is not fully explained by the associated structural brain lesion such as ACC, pontine hypoplasia, and others, as recent studies have suggested that Vici syndrome has a neurodegenerative pattern with progressive loss of skills and profound acquired microcephaly. Furthermore, the EPG5 genes were linked to early-onset epileptic encephalopathies, respiratory chain enzyme abnormalities, and secondary mitochondrial dysfunction as a possible downstream effect of defective autophagy [9].

The genetic testing of our patient revealed a homozygous likely pathogenic variant in the EPG5 gene confirming the clinical diagnosis of Vici syndrome. The c. $1252+1 \mathrm{G}>\mathrm{T}$ substitution that we discovered affects the first nucleotide of intron 3 and, to date, has not been reported in Vici syndrome patients. It is predicted to disrupt the highly conserved donor splice site $[19,20]$ and cause skipping of exon 3 and the complete loss of functional EPG5 protein either through protein truncation or, more likely, through nonsense-mediated decay. In line with this finding, the majority of the previously reported EPG5 pathogenic variants are nonsense, frameshift, and splice site changes indicating a loss of function mechanism in Vici syndrome patients. Unfortunately, no RNA or cell sample was available from the parents of the index patient or any other family member potentially carrying the c. $1252+1 \mathrm{G}>\mathrm{T}$ change. Thus, we were unable to experimentally validate the occurrence of altered splicing and nonsense-mediated RNA decay. 
As for clinicians, suspicion of Vici syndrome is based on the characteristic clinical manifestations. Differential diagnosis based on other syndromes showing phenotypical overlap with Vici syndrome [6], or other neurometabolic etiologies of agenesis of the corpus callosum [21], has been suggested. One approach is to be aware of other differential diagnoses particularly other inherited hypopigmentation disorders, and especially those associated with neurological manifestations and structural brain lesions. This approach is a real challenge due to overlapping features. These rare disorders could include gray hair syndromes like Griscelli syndrome (GS), Chediak-Higashi syndrome (CHS), and oculocerebral hypopigmentation syndrome, cross-type (OHS). However, they all share the presence of silvery gray hair and the characteristic hair trichogram which is not commonly found in cases of Vici syndrome. Besides, CHS is characterized by giant azurophilic granules within neutrophils and regular small melanin granules visible in a trichogram while the neurological manifestations are either primary (developmental and degenerative) or secondary to an accelerated phase of hemophagocytic lymphohistiocytosis (CNS-HLH) [22]. Unlike CHS, the trichogram of GS shows small and large unevenly distributed melanin clumps. Neurological manifestations are found in all types except for GS type 3 [23]. Neurological presentations of GS1 are mostly primary due to myosin-Va deficiency [24], while those of GS2 are either due to CNS infections, due to a consequence of the associated immune deficiency, or due to CNS-HLH [25]. Although hypopigmentation may not be a consistent major finding in both Prader-Willi and Angelman syndromes, it should be included in the differential diagnosis and can be recognized by their characteristic somatic and behavioral problems [26, 27]. Laboratory investigations might narrow the list such as in cases of suspected phenylketonuria, which can be excluded by phenylalanine level in the blood and urine, and Menkes syndrome by measuring serum copper and ceruloplasmin in a child with short friable sparse hair (Table 1).

Counseling for the parents involved discussing their concerns about themselves, their healthy older child, and their future pregnancy probabilities. They were told that they were both carriers which means that both only have a genetic change that does not cause any health problems for them. For their older healthy child, they were advised to perform molecular testing to determine if he was a carrier or not affected. But the most important concerns for them were about the next pregnancies; genetic counseling was provided, and they were advised to perform prenatal diagnosis if they are intending to have other children.

Regarding patient prognosis, Vici syndrome is a devastating neurodegenerative disease with progressive multisystem pathology. The prognosis is variable with reported attenuated Vici syndrome phenotype [28]. However, most of the cases had a poor prognosis and a median survival time of 24 months. Cardiomyopathy and recurrent infections, the causes of death of the current case, are the most common causes of death [9].

\section{Conclusion}

The accurate diagnosis of such a rare disease with molecular confirmation is vital for proper clinical decision-making, genetic counseling of the affected families, and future genotype-phenotype correlation studies.

\section{Abbreviations \\ ABR: Auditory Brainstem Response test; ACC: Agenesis of the corpus callosum; AR: Autosomal recessive; CADD: Combined Annotation-Dependent Depletion; CBC: Complete blood count; CD: Cluster of differentiation; CHS: Chediak-Higashi syndrome; CNS: Central nervous system; \\ DNA: Deoxyribonucleic acid; ECHO: Echocardiography; EF: Ejection fraction; EPG5: Ectopic P-granules autophagy protein 5; GHSs: Gray hair syndromes; GnomAD: Genome Aggregation Database; GS: Griscelli syndrome; HLH: Hemophagocytic lymphohistiocytosis; IgA: Immunoglobulin A; IgG: Immunoglobulin G; IgM: Immunoglobulin M; IVIG: Intravenous immunoglobulin; LVEDd: Left ventricular end-diastolic dilatation; MRI: Magnetic resonance imaging; MYO5A: Myosin-Va; NICU: Neonatal intensive care unit; OHS: Oculocerebral hypopigmentation syndrome; PAH: Phenylalanine hydroxylase; PFO: Patent foramen oval; SNHL: Sensory neural hearing loss}

\section{Acknowledgements}

The authors would like to thank the parents of the presented case for their approval of participation and the kind contribution of their samples.

\section{Authors' contributions}

MAM clinically followed up the index case regarding his neurological manifestations. AA clinically diagnosed and followed up the index case. CP conducted the genetic analysis of the index case and his parents. MD conducted the hair trichogram. All authors participated in the writing and revision process of the manuscript. All authors have read and approved the final manuscript.

\section{Authors' information}

CP is an employee of CENTOGENE AG (Rostock, Germany).

\section{Funding}

None.

\section{Availability of data and materials}

All data used during this report are included in this published article. Further data are available from the corresponding author on reasonable request.

\section{Ethics approval and consent to participate}

The manuscript had the approval of the Ethical Committee of the Faculty of Medicine, Alexandria University. Written informed consent was taken from the parent of the index case (legal guardian) for participation.

\section{Consent for publication}

Written consent was taken from the parent of the index case for publication.

\section{Competing interests}

The authors declare no competing interest.

\section{Author details}

${ }^{1}$ Department of Pediatrics, Neurology Unit, Faculty of Medicine, Alexandria University, Alexandria, Egypt. ${ }^{2}$ Department of Pediatrics, Genetic Unit, Faculty of Medicine, Alexandria University, Alexandria, Egypt. ${ }^{3}$ Cenotogene AG, 
Rostock, Germany. ${ }^{4}$ Department of Dermatology, Venereology \& Andrology, Faculty of Medicine, Alexandria University, Alexandria, Egypt.

Received: 16 May 2020 Accepted: 16 October 2020

Published online: 11 December 2020

\section{References}

1. Dionisi Vici C, Sabetta G, Gambarara M, Vigevano F, Bertini E, Boldrini R et al (1988) Agenesis of the corpus callosum, combined immunodeficiency, bilateral cataract, and hypopigmentation in two brothers. Am J Med Genet 29(1):1-8

2. Alzahrani A, Alghamdi AA, Waggass R (2018) A Saudi infant with Vici syndrome: case report and literature review. Open Access Maced J Med Sci 6(6):1081-1084

3. Kane MS, Zhao J, Muskett J, Diplock A, Srivastava S, Hauser N et al (2019) EPG5 variants with modest functional impact result in an ameliorated and primarily neurological phenotype in a 3.5-year-old patient with Vici syndrome. Neuropediatrics 50(04):257-261

4. Vojcek E, Keszthelyi TM, Jávorszky E, Balogh L, Tory K (2020) EPG5 C.1007A > $\mathrm{G}$ mutation in a sibling pair with rapidly progressing Vici syndrome. Ann Human Genet 84(1):80-86

5. Cullup T, Kho AL, Dionisi-Vici C, Brandmeier B, Smith F, Urry Z et al (2013) Recessive mutations in EPG5 cause Vici syndrome, a multisystem disorder with defective autophagy. Nat Genet 45(1):83-87

6. Byrne S, Dionisi-Vici C, Smith L, Gautel M, Jungbluth H (2016) Vici syndrome: a review. Orphanet J Rare Dis 11(1):21

7. Richards S, Aziz N, Bale S, Bick D, Das S, Gastier-Foster J et al (2015) Standards and guidelines for the interpretation of sequence variants: a joint consensus recommendation of the American College of Medical Genetics and Genomics and the Association for Molecular Pathology. Genet Med 17(5):405-424

8. Rentzsch P, Witten D, Cooper GM, Shendure J, Kircher M (2019) CADD predicting the deleteriousness of variants throughout the human genome. Nucleic Acids Res 47(D1):D886-Dd94

9. Byrne S, Jansen L, U-King-Im JM, Siddiqui A, Lidov HG, Bodi I et al (2016) EPG5-related Vici syndrome: a paradigm of neurodevelopmental disorders with defective autophagy. Brain 139(Pt 3):765-781

10. McClelland V, Cullup T, Bodi I, Ruddy D, Buj-Bello A, Biancalana V et al (2010) Vici syndrome associated with sensorineural hearing loss and evidence of neuromuscular involvement on muscle biopsy. Am J Med Genet A 152a(3):741-747

11. Al-Owain M, Al-Hashem A, Al-Muhaizea M, Humaidan H, Al-Hindi H, AlHomoud I et al (2010) Vici syndrome associated with unilateral lung hypoplasia and myopathy. Am J Med Genet A 152a(7):1849-1853

12. Huenerberg K, Hudspeth M, Bergmann S, Pai S, Singh B, Duong A (2016) Two cases of Vici syndrome associated with idiopathic thrombocytopenic purpura (ITP) with a review of the literature. Am J Med Genet A 170a(5): 1343-1346

13. Miyata R, Hayashi M, Sato H, Sugawara Y, Yui T, Araki S et al (2007) Sibling cases of Vici syndrome: sleep abnormalities and complications of renal tubular acidosis. Am J Med Genet A 143a(2):189-194

14. Waggass R (2015) Dilated cardiomyopathy in a Saudi male infant with Vic syndrome. Heart Lung Circ 24:S428

15. Said E, Soler D, Sewry C (2012) Vici syndrome--a rapidly progressive neurodegenerative disorder with hypopigmentation, immunodeficiency and myopathic changes on muscle biopsy. Am J Med Genet A 158a(2):440-444

16. del Campo M, Hall BD, Aeby A, Nassogne MC, Verloes A, Roche $C$ et al (1999) Albinism and agenesis of the corpus callosum with profound developmental delay: Vici syndrome, evidence for autosomal recessive inheritance. Am J Med Genet 85(5):479-485

17. Ozkale M, Erol I, Gumus A, Ozkale Y, Alehan F (2012) Vici syndrome associated with sensorineural hearing loss and laryngomalacia. Pediatr Neurol 47(5):375-378

18. Finocchi A, Angelino G, Cantarutti N, Corbari M, Bevivino E, Cascioli S et al (2012) Immunodeficiency in Vici syndrome: a heterogeneous phenotype. Am J Med Genet A 158a(2):434-439

19. Reese MG, Eeckman FH, Kulp D, Haussler D (1997) Improved splice site detection in Genie. J Comput Biol. 4(3):311-323

20. Splice Site Prediction by Neural Network. Available from: https://www. fruitfly.org/seq_tools/splice.html
21. Maillard C, Cavallin M, Piquand K, Philbert M, Bault JP, Millischer AE et al (2017) Prenatal and postnatal presentations of corpus callosum agenesis with polymicrogyria caused by EGP5 mutation. Am J Med Genet A. 173(3): 706-711

22. Sharma P, Nicoli E-R, Serra-Vinardell J, Morimoto M, Toro C, Malicdan MCV et al (2019) Chediak-Higashi syndrome: a review of the past, present, and future. Drug Discovery Today: Disease Models

23. Abd Elmaksoud MS, Gomaa NS, Azouz HG, CNV O, Ho CT, Omar TE et al (2020) Genetic analysis in three Egyptian patients with Griscelli syndrome type 1 reveals new nonsense mutations in MYO5A. Clin Exp Dermatol 45(6): 789-792

24. Hammer JA 3rd, Wagner W (2013) Functions of class $V$ myosins in neurons. J Biol Chem. 288(40):28428-28434

25. Meeths M, Bryceson YT, Rudd E, Zheng C, Wood SM, Ramme K et al (2010) Clinical presentation of Griscelli syndrome type 2 and spectrum of RAB27A mutations. Pediatr Blood Cancer 54(4):563-572

26. Gunay-Aygun M, Schwartz S, Heeger S, O'Riordan MA, Cassidy SB (2001) The changing purpose of Prader-Willi syndrome clinical diagnostic criteria and proposed revised criteria. Pediatrics 108(5):E92

27. Bird LM (2014) Angelman syndrome: review of clinical and molecular aspects. Appl Clin Genet 7:93-104

28. Waldrop MA, Gumienny F, Boue D, de Los RE, Shell R, Weiss RB et al (2018) Low-level expression of EPG5 leads to an attenuated Vici syndrome phenotype. Am J Med Genet A 176(5):1207-1211

\section{Publisher's Note}

Springer Nature remains neutral with regard to jurisdictional claims in published maps and institutional affiliations.

\section{Submit your manuscript to a SpringerOpen ${ }^{\circ}$ journal and benefit from:}

- Convenient online submission

- Rigorous peer review

- Open access: articles freely available online

- High visibility within the field

- Retaining the copyright to your article

Submit your next manuscript at $>$ springeropen.com 